\title{
Erratum: A rapid immunization strategy with a live-attenuated tetravalent dengue vaccine elicits protective neutralizing antibody responses in non-human primates
}

\section{Frontiers Production Office *}

Frontiers Production Office, Frontiers, Switzerland

${ }^{*}$ Correspondence: production.office@frontiersin.org

Approved by:

Immunology Editorial Office, Frontiers, Switzerland

Keywords: dengue, vaccine, non-human primates, neutralizing antibodies, needle-free delivery, $\mathrm{T}$ cell responses

\section{An erratum on}

A rapid immunization strategy with a live-attenuated tetravalent dengue vaccine elicits protective neutralizing antibody responses in non-human primates by Ambuel Y, Young G, Brewoo JN, Paykel J, Weisgrau KL, Rakasz EG, Haller AA, Royals $M$, Huang CY-H, Capuano S, Stinchcomb DT, Partidos CD and Osorio JE. Front Immunol (2014) 5:263. doi: 10.3389/fimmu.2014.00263
Reason for Erratum:

In Table 4 the text of subheadings was changed due to a typesetting error. This error does not change the scientific conclusions of the article in any way. The publisher apologizes for this error and the correct version of Table 4 appears below.

Received: 27 August 2014; accepted: 27 August 2014; published online: 15 September 2014.

Citation: Frontiers Production Office (2014) Erratum:

A rapid immunization strategy with a live-attenuated tetravalent dengue vaccine elicits protective neutralizing antibody responses in non-human primates. Front. Immunol. 5:436. doi: 10.3389/fimmu.2014.00436

This article was submitted to Microbial Immunology, a section of the journal Frontiers in Immunology.

Copyright () 2014 Frontiers Production Office. This is an open-access article distributed under the terms of the Creative Commons Attribution License (CC BY). The use, distribution or reproduction in other forums is permitted, provided the original author(s) or licensor are credited and that the original publication in this journal is cited, in accordance with accepted academic practice. No use, distribution or reproduction is permitted which does not comply with these terms.

Table 4 | Kinetics of neutralizing antibody responses in animals vaccinated with TDV SC or ID using the PharmaJet device

\begin{tabular}{|c|c|c|c|c|c|c|c|c|c|c|c|c|c|}
\hline \multirow[t]{2}{*}{ NHP ID } & \multirow[t]{2}{*}{ Vaccine regimen } & \multicolumn{4}{|c|}{ Day 30} & \multicolumn{4}{|c|}{ Day 53} & \multicolumn{4}{|c|}{ Day 88} \\
\hline & & D1 & D2 & D3 & D4 & D1 & D2 & D3 & D4 & D1 & D2 & D3 & D4 \\
\hline CY0504 & $\mathrm{PhJ} / \mathrm{ID}$ & 80 & 640 & 40 & 10 & 40 & 2560 & 40 & 5 & 80 & 2560 & 20 & 40 \\
\hline CY0505 & & 320 & 1280 & 2560 & 320 & 160 & 640 & 640 & 160 & 80 & 640 & 160 & 40 \\
\hline CY0473 & 0,0 & 2560 & 10240 & 160 & 40 & 640 & 5120 & 80 & 20 & 320 & 1280 & 40 & 20 \\
\hline CY0474 & $\mathrm{PhJ} / \mathrm{SC}$ & 1280 & 320 & 1280 & 160 & 640 & 640 & 640 & 160 & 320 & 320 & 160 & 80 \\
\hline \multirow[t]{2}{*}{ CY0475 } & & 640 & 320 & 640 & 320 & 640 & 320 & 320 & 80 & 160 & 320 & 160 & 160 \\
\hline & GMT & 1280 & 1016 & 508 & 127 & 640 & 1016 & 254 & 64 & 254 & 508 & 101 & 64 \\
\hline CY0493 & 0,60 & 160 & 2560 & 160 & 20 & 80 & 2560 & 10 & 20 & 320 & 2560 & 80 & 40 \\
\hline
\end{tabular}

$G M T^{*}=$ geometric mean titer. 